\title{
Factors associated with depressive symptoms in a sample of Brazilian medical students
}

\author{
Fatores associados a sintomas depressivos entre \\ estudantes de medicina da UNILUS
}

Paula Natalie Arraes Guedes Macedo ${ }^{\mathrm{I}}$

Luciana Loureiro Nardotto ${ }^{\mathrm{I}}$

Luiz Henrique Junqueira Dieckmann ${ }^{\text {II }}$

Yngrid Dieguez Ferreira ${ }^{\mathrm{I}}$

Barbara Arraes Guedes Macedo ${ }^{\text {III }}$

Maria Aparecida Pedrosa dos Santos ${ }^{I}$

Mario Alfredo De Marco ${ }^{\mathrm{II}}$

\section{KEY WORDS \\ - Depression \\ - Students \\ - Medicine \\ - Prevalence}

Recebido em: 12/09/2008

Reencaminhado em: 23/10/2008 Reencaminhado em: 29/04/2009 Aprovado em: 16/05/2009

\section{R E S U M O}

Objetivos: 1- Verificar prevalência de sintomas depressivos nos estudantes de medicina do $1^{\circ}$ a $4^{\mathrm{o}}$ ano através do Inventário de Depressão de Beck (IDB). 2- Estabelecer correlações entre os fatores questionados e a incidência de maior ou menor pontuação no IDB. 3- Investigar relação entre a prevalência de sintomas depressivos e a procura por atendimento psicológico oferecido pela Universidade Lusíada. Método: Desenho transversal realizado com 290 acadêmicos do curso de medicina, do $1^{\mathrm{o}}$ ao $4^{\mathrm{o}}$ ano. Realizada aplicação do IDB, questionário sócio-demográfico e avaliação sobre satisfação com curso. Resultados:Da amostra estudada, 59\% são mulheres e $41 \%$ homens. O escore médio do IDB foi de 6,3 com DP de 5,8. A prevalência total de sintomas depressivos foi de $23,1 \%$. As seguintes relações apresentaram significância estatística $(P<0,05)$ : Dos estudantes que afirmam que o curso não corresponde às expectativas iniciais, dos estudantes insatisfeitos com o curso e dos estudantes procedentes do Interior do Estado (20,5\%; 12,5\% e 24,4\% da amostra total, respectivamente), 40\%, 36,1\% e 36,4\% respectivamente, tem escore compatível com algum grau de depressão. Conclusão:O presente estudo mostrou que há maior prevalência de sintomas depressivos nos estudantes de Medicina que na população geral. 


\section{INTRODUCTION}

Mood disorders include a wide group of psychiatric conditions in which the fundamental disturbance is a change of mood or affect, generally accompanied by a change in overall level of activity. Most of these disorders tend to be recurrent, and individual episodes can often be related to stressful situations. This large group includes depressive disorder and dysthymia, which is also considered a mood disorder, characterized by the DSM-IV as a chronically depressed mood that occurs for most of the day, for more days than not for at least two years (Criterion A). During periods of depressed mood, at least two of the following additional symptoms are present: hyperphagia, decreased appetite, insomnia, hypersomnia, low energy or fatigue, low self-esteem, poor concentration or difficulty making decisions, and feelings of hopelessness (Criterion B).

Several individuals experience mood disorder before the onset of a major depressive disorder (single episode). Some evidence suggests that these individuals are more prone to additional depressive episodes, experience partial recovery between episodes, and may need additional treatment for the acute phase and a longer period of continued treatment, in order to acquire and maintain a more durable euthymic state. The severity of the initial major depressive episode appears to predict its persistence. Studies suggest that psychosocial events (stressors) may play a more significant role in precipitating the first or second episode of major depressive disorder and a lesser role at the beginning of subsequent episodes.

Mood disorder and major depressive disorder are differentiated on the basis of severity, chronicity, and persistence. In major depressive disorder, the depressed mood must be present during most of the day, almost every day for a minimum of two weeks, while in mood disorder it must be present on most days for at least two years.

It is estimated that $17 \%$ of adults suffer from a depressive illness at some period in life. Thus, we can ascertain that medical students, facing stressful factors during their academic routine (more working hours compared to other courses, assuming responsibility for human life, pressure to learn, increased labor market demand, the need in some situations to leave home and live temporarily in a strange city, among others factors) or by stage of life (the transition to adulthood), would be more susceptible to mood disorders or depressive episodes at some time during medical school. Studies show $15 \%$ to $25 \%$ of university students having some kind of psychiatric disorder during their academic training ${ }^{1-4}$, especially depressive disorders and anxiety ${ }^{5-8}$. Most of these studies were conducted among medical students $^{9-15}$, and estimated prevalence of depressive disorders in this population ranges from $8 \%$ to $17 \%$.
One problem closely related to depression is suicide. Some studies indicate a high risk of suicide among university students, particularly among medical students ${ }^{16}$, where it is the second leading cause of death, next to accidents. In the general population, the suicide rate in men is more than four times that in women, but female physicians show comparable rates to those of their male counterparts ${ }^{17}$.

Studies have focused on different stressors that could influence the prevalence of depression among university students. In medicine, the main stressors occur at the beginning (enormous amounts of information, changes in study methods, and long working hours) and end (uncertainty with regards to one's own competence and the labor market that the student begins to glimpse $)^{6,18}$. Studies have shown that students with lower academic performance were more prone to depressive symptoms ${ }^{19}$. Perfectionism, a trait found in many medical students, bears a strong relationship to psychological stress.

The Program for Psychological and Pedagogical Support for Medical Students (PROAC) was implemented in February 2000, based on the observed need to provide psychological support for medical students experiencing various types of crises, especially for those who were from out of town and thus away from their original family and social support network. The program faced initial resistance, such as discrimination, uncertainty, and insecurity among the students themselves.

The Beck Depression Inventory or BDI (self-applied scale), probably the most widely used index of self-assessed depression (both in research and clinical practice), was used to collect data for this study.

The study's objectives were to examine the occurrence of mood disorders among students at the Santos School of Medicine (UNILUS) and correlate target factors with incidence of higher and lower BDI scores, verify whether the prevalence was higher than in the general population, and determine whether students were seeking psychological help offered by the university (PROAC).

\section{METHODOLOGY}

\section{Study design and subjects}

This was a cross-sectional study of first to fourth-year medical students at the Centro Universitário Lusíada, resulting in a sample of 290 participants (among a potential pool of approximately 480 medical students). Non-participation was due to refusal to complete the questionnaire. The study was approved by the UNILUS Institutional Review Board. 


\section{Inclusion criteria}

All participants present on the days the questionnaire was applied and that agreed to complete the questionnaire were included in the study, and written informed consent was obtained from all subjects.

\section{Exclusion criteria}

All students who refused to answer the questionnaire were excluded.

\section{INSTRUMENT}

The research instrument was a questionnaire based on the BDI, and that also included questions on the demand for psychological care offered by PROAC, demographics (including home town), and expectations and satisfaction concerning the medical course.

The original BDI consists of 21 items, including symptoms and attitudes, with intensity varying from 0 to 3 . The items relate to sadness, pessimism, sense of failure, dissatisfaction, feelings of guilt, sense of punishment, self-denigration, self-accusations, suicidal ideas, weeping, irritability, social retraction, indecision, distortion of body image, inhibition to work, sleep disturbance, fatigue, loss of appetite, weight loss, somatic concern, and decreased libido (Attachment 1).

There are various proposed cutoff points to distinguish between levels of depression using the $\mathrm{BDI}^{20-24}$. According to Beck ${ }^{25}$, choice of the appropriate cutoff depends on the nature of the sample and the study's objectives ${ }^{26}$.

The Center for Cognitive Therapy ${ }^{25}$ recommends the following cutoff points, which were used in this study: 9/10, 18/19, and 29/30. Scores below 10 represent subjects without symptoms of depression or minimal symptoms; 10 to 18 includes individuals with symptoms of mild to moderate depression; symptoms of moderate to severe depression produce scores from 19 to 29 ; and individuals with symptoms of severe depression have scores above 30 and may reach 63 . The BDI is not intended for diagnostic purposes. As a standardized procedure, it may fail to detect "masked depression, anxiety" in individuals who deny their emotional suffering; meanwhile, it can overestimate the disorder, since many individuals have physical causes for their fatigue and other somatic symptoms, which are important in any instrument used to detect emotional disorders.

\section{Statistical analysis}

Statistical significance was set at $p<0.05$. The data were analyzed with SPSS 13.0, using a 95\% confidence interval.
Quantitative variables were described using means and standard deviations. For group comparison of categorical variables, analyses used the chi-square test and Fisher's exact test.

Qualitative variables were described using frequencies and percentages.

\section{Risks and Difficulties}

This study did not pose any risks for subjects, since it did not involve any invasive procedures or methods, and the collected data were kept confidential.

Due to the nature of the study and to ensure reliability of the material, participating subjects were not identified in any way, and referral for counseling was thus not possible for students identified as having possible depressive episodes. The focus was to provide general orientation by publicizing PROAC's activities and objectives.

\section{RESULTS}

From the initial pool of 480 medical students (342 women and $212 \mathrm{men}), 290$ participated in the study (60.4\%). Distribution of females and males was $59 \%$ and $41 \%$, respectively. Depressive symptoms were present in $21.3 \%$ of male students $(17.7 \%$ mild/moderate; $0.9 \%$ severe) and $24.2 \%$ of females $(21.2 \%$ mild/moderate; $3 \%$ moderate/severe), but this difference was not statistically significant. Mean age of sample subjects was 21.6 years (SD 2)

Mean BDI score was 6.3, out of a total of 63 points (SD 5.8; range 0-40). The highest score on an individual question was question number 17 (degree of physical fatigue from routine activities) with a mean of 0.7 (maximum possible score on this question is 3 points) and a SD of 0.7 .

Graph 1 shows the distribution and degree of depression by course year in medical school, with a higher prevalence of depressive symptoms in second and third-year students $(25.9 \%$ and $25.1 \%$, respectively, of mild to moderate depressive symptoms). However, these results were not statistically significant ( $\mathrm{p}>0.05)$.

As shown in graphe 1 , the first and second years showed the highest prevalence of severe depression $(1.1 \%$ and $1.7 \%$, respectively), but were not statistically different from the third and fourth years $(\mathrm{P}>0.05)$.

Students dissatisfied with the course represented $12.5 \%$ of the total sample, among which $36.1 \%$ had scores that were consistent with some degree of depressive symptoms $(28.1 \%$ mild/moderate depression, $2.6 \%$ moderate/severe depression, $5.2 \%$ severe depression) $(p<0.05)$. Dissatisfied students showed more depressive symptoms than satisfied ones, and also showed more severe depression than their satisfied peers $(\mathrm{p}<0.05)$. 
Graph 1

Prevalence of depressive svmptoms bv course vear in medical school.

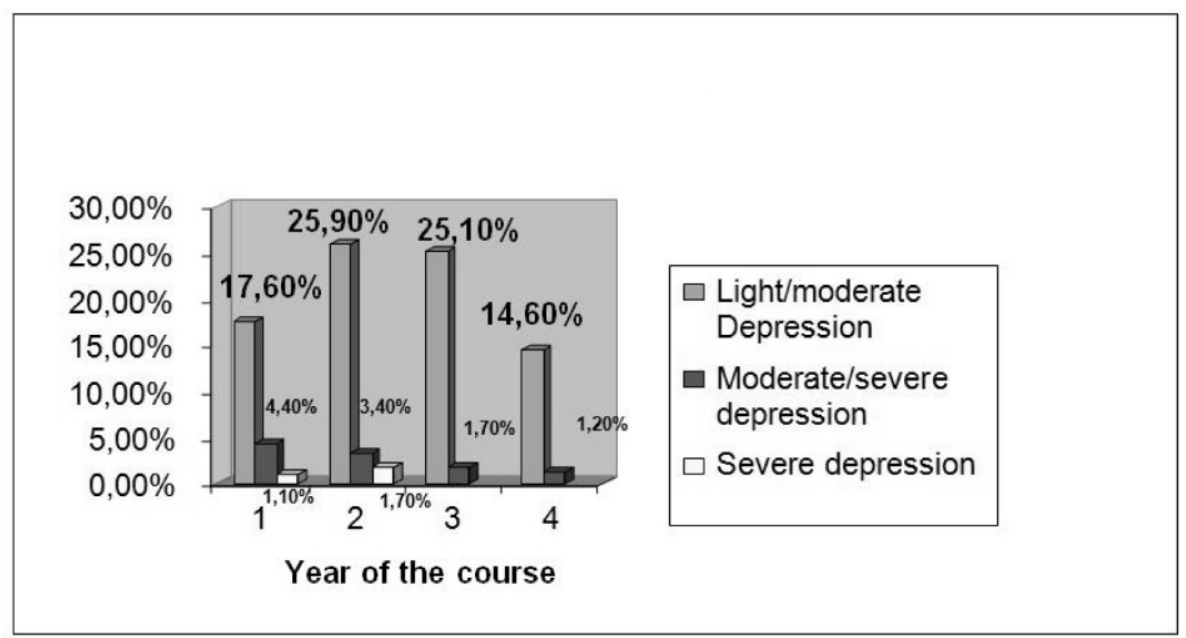

For $79.5 \%$ of the sample as a whole, the course met their initial expectations, leaving 20.5\% whose initial expectations were not met. Among the latter, prevalence of depressive symptoms was $40 \%$ (35.4\% with mild / moderate symptoms, 3.1\% moderate/severe symptoms, and $1.5 \%$ severe), much higher than among students whose initial expectations were met (highly significant, with $\mathrm{p}<0.001)$. Among dissatisfied students, $85.3 \%$ felt that the course failed to meet their initial expectations, as compared to only $20.5 \%$ of the sample as a whole.

In this particular subgroup of the sample (students that were dissatisfied with the course), only $12.8 \%$ sought help from PROAC, a proportion that was no different from the overall sample (13.1\%). When submitted to the validation test, there was no statistical relationship between the demand for help from PROAC and higher or lower prevalence of mild/moderate or severe depressive symptoms in that particular sub-sample $(\mathrm{p}>0.05)$.

Prevalence of depressive symptoms at the medical school was $23.1 \%$, based on the BDI. This total was distributed differently according to whether the student was local or from out of town, as shown in Table 2. Out-of-town students (those from the interior of the São Paulo State) showed a statistically significant association ( $\mathrm{p}<0.05)$ with depressive symptoms $(36.40 \%)$.

In the sample as a whole, $32.4 \%$ lived alone, $25.9 \%$ with family, $39.7 \%$ with friends, and $1.7 \%$ in other living arrangements (there was no statistically significant difference; $p>0.05$ ). Overall prevalence of depressive symptoms in first to fourth-year medical students was $23.1 \%$ (19.9\% with symptoms of mild / moderate depression, $2.6 \%$ moderate/severe, and $0.6 \%$ severe symptoms).

\section{DISCUSSION}

First and second-year medical students at the Centro Universitário Lusíada are limited to highly theoretical study. The only practical study in the first two years is in laboratories.

The first contact with patients occurs in the third year. In the fourth year, lecture classes predominate again over practical classes. The fifth and sixth years are the "medical internship", when students' contact with patients is intense, but brief.

Depressive symptoms were slightly more prevalent in women, with a $24.2 \%$ incidence of scores consistent with some degree of depressive symptoms, as compared to $21.3 \%$ in men. This difference was not statistically significant $(\mathrm{p}>0.05)$. The result is similar to that of a study of medical students at the University of Maringá, where there was no statistically significant difference in the incidence of depression in female medical students as compared to the general population ${ }^{26}$.

There was a decrease in incidence of depressive symptoms from the first to fourth year (from $23.1 \%$ to $15.8 \%$ ), as well as in severity $(5.5 \%$ of moderate to severe depression in the first year, compared to $1.20 \%$ in the fourth year). The highest percentage of depressive symptoms was in students from the interior of São Paulo State. This was probably due to the difference in habits between larger and coastal cities and the distance from family support. The $\mathrm{p}$ was $<0.05$, showing a significant correlation with depressive symptoms. 
Table 1

Prevalence of depressive symptoms as related to course satisfaction.

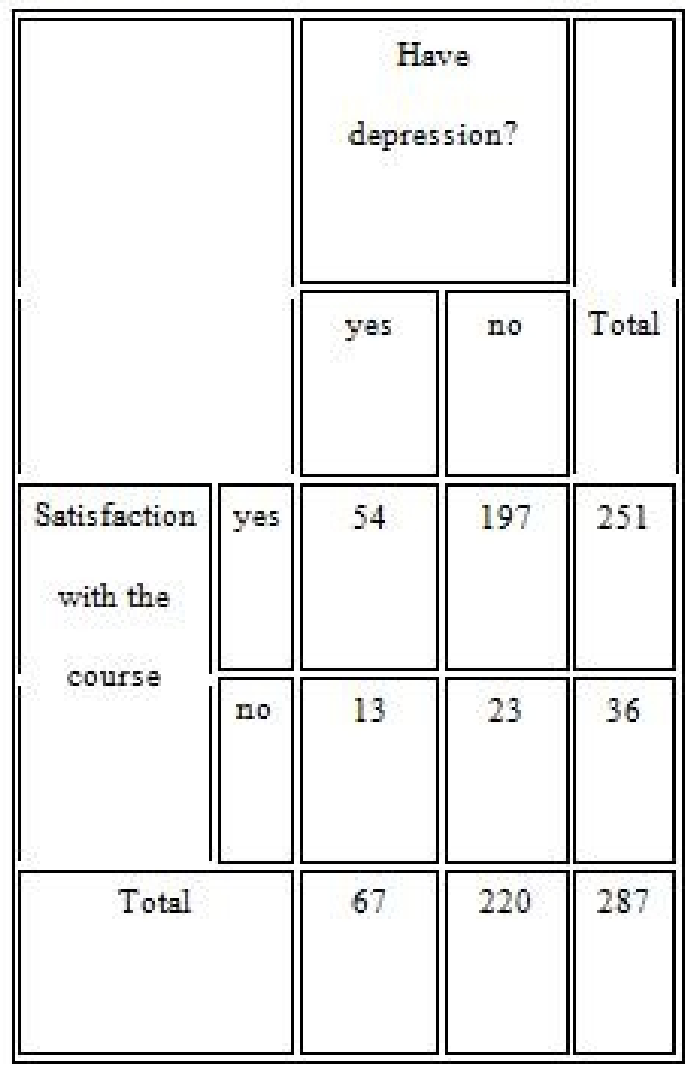

Statistical tests

\begin{tabular}{||c||c||c|c||c||c||}
\hline & Value & DF & $\begin{array}{c}\text { Asymp. Sig. (2- } \\
\text { sided) }\end{array}$ & $\begin{array}{c}\text { Exact Sig. (2- } \\
\text { sided) }\end{array}$ & $\begin{array}{c}\text { Exact Sig. (1- } \\
\text { sided) }\end{array}$ \\
\hline Pearson Chi-Square & 3,749(b) & 1 &, 053 & & \\
\hline \hline Fisher's Exact Test & & & & & \\
\hline \hline Number of valid & & & & & \\
\hline cases & & & & \\
\hline
\end{tabular}


Table 2

Prevalence of depressive symptoms related to satisfaction of original expectations.

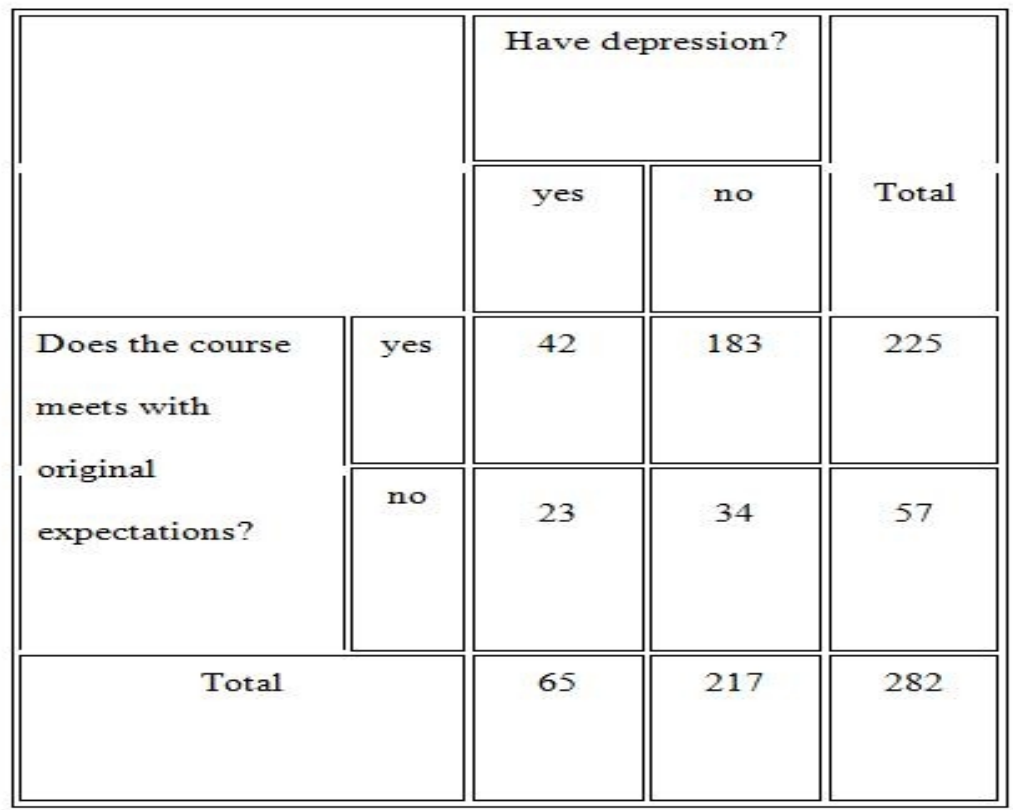

Statistical tests

\begin{tabular}{|c|c|c|c|c|c|}
\hline & Value & DF & $\begin{array}{l}\text { Asymp- } \\
\text { Sig. (2- } \\
\text { sided) }\end{array}$ & $\begin{array}{l}\text { Exact } \\
\text { Sig. (2- } \\
\text { sided) }\end{array}$ & $\begin{array}{l}\text { Exact } \\
\text { Sig. (1- } \\
\text { sided) }\end{array}$ \\
\hline $\begin{array}{c}\text { Pearson Chi- } \\
\text { Square }\end{array}$ & $12,056(b)$ & 1 & .001 & & \\
\hline $\begin{array}{c}\text { Fisher's Exact } \\
\text { Test }\end{array}$ & & & & $=001$ & $=001$ \\
\hline $\begin{array}{c}\text { Number of valid } \\
\text { cases }\end{array}$ & 282 & & & & \\
\hline
\end{tabular}


Table 3

Prevalence of depressive symptoms related to student's original place of residence

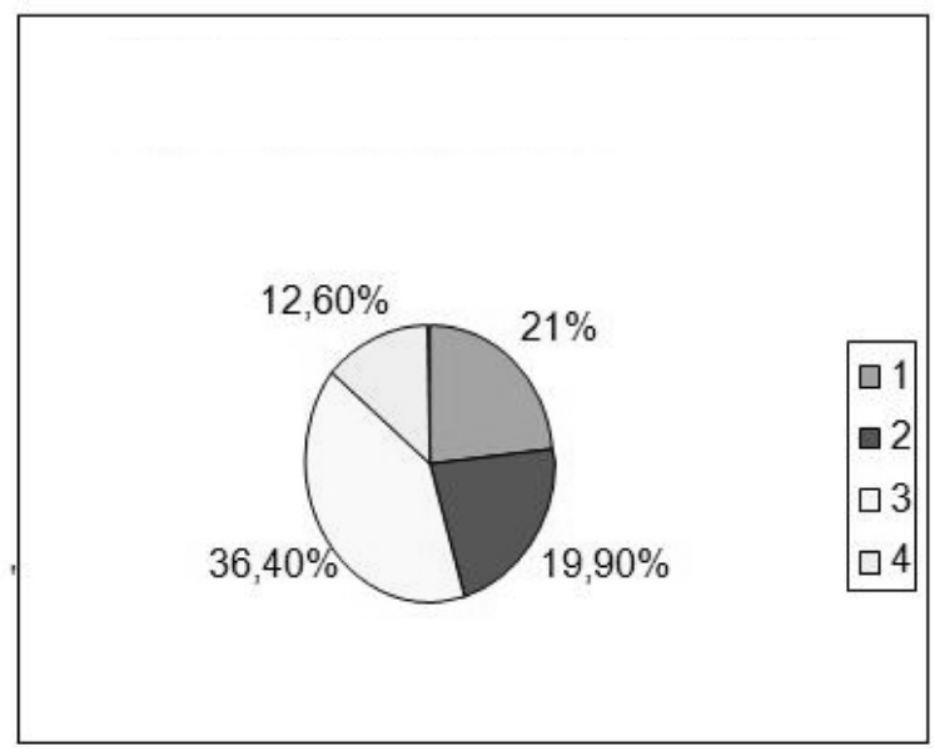

1- Santos

2- São Paulo

3- São Paulo's country

4- Other States

Statistical tests

\begin{tabular}{||c||c||c|c||}
\hline \multicolumn{1}{||||||||}{} & Valor & DF & Asymp. \\
Sig. (2- \\
sided)
\end{tabular}


There was no statistically significant difference in the degree of depressive symptoms when comparing students who lived alone or with family, friends, or others.

Course dissatisfaction $(12.5 \%)$ was significantly correlated ( $p<0.05$ ) with mild/moderate/severe depressive symptoms ( $36.1 \%$ of students dissatisfied with the course). The correlation remained $(\mathrm{p}<0.05)$ when considering only the group with severe depressive symptoms (5.2\%).

Only $12.8 \%$ of students that were dissatisfied with the course sought help from PROAC, thus emphasizing the importance of investigating factors that potentially determine this behavior. As a hypothesis, a potentially important factor is the prejudice and fear of how classmates may view seeking psychological help. The proportion did not differ from that of the overall sample $(13.1 \%)$, and there was no statistically significant difference in depressive symptoms between those seeking (versus not seeking) help from PROAC.

Failure of the course to meet original expectations (20.5\% of the sample) was strongly associated ( $\mathrm{p}<0.001$ ) with presence of depressive symptoms (40\% overall: mild/moderate in $35.4 \%$; moderate/severe in $3.1 \%$; and severe in $1.5 \%$ ). However, it was not possible to rule out that negative perceptions of the course were related to presence of depressive symptoms.

Mean BDI was 6.3 (SD 5.8). This result was consistent with that found in the literature regarding students (depending on the country and author of the study, the mean number of points on the scale tends to vary). Bourque \& Beaudette ${ }^{27}$, in 1992, found a mean BDI of 6.1 (SD 5.9); Conde \& Useros ${ }^{28}$, in Canada, found a mean of 7.6 (SD 6.7); and Gorestein et $\mathrm{al}^{29}$, in a study in Brazil in 1995, found a mean of 8.5 and SD of 7 (all with $p<0.05$ ).

The question with the highest scores on the scale was number 17, referring to the degree of physical fatigue from routine activities, with a mean of 0.7 and SD of 0.7 (total possible points on the question was three). This may not have been highly relevant in the case of medical students, whose routine activities are usually intense and require great physical effort.

According to a multi-center study by Almeida Filho ${ }^{30}$, prevalence of depressive disorder in the overall population in Greater Metropolitan Sao Paulo, Brasilia, and Porto Alegre ranged from $2.8 \%$ to $10.2 \%$, as compared to $7.8 \%$ to $15 \%$ in the United States population, with up to $25 \%$ in women.

Finally, the presence of depressive symptoms in medical students at the Centro Universitário Lusíada was 23.1\%, when using the cutoff points recommended by the Center for Cognitive Therapy. Thus, prevalence of depressive symptoms in medi- cal students was higher than in the United States population and much higher than in the overall Brazilian population.

The results were consistent with studies in the United States, like Supe ${ }^{17}$, Helmers ${ }^{18}$, Rosal ${ }^{19}$, Foltyn in Poland ${ }^{20}$, and Stewart in the United Kingdom ${ }^{15}$, showing that prevalence of depression among medical students in these countries is also higher than in the general population. The data suggest that medical education as currently organized is a risk factor for increased incidence of depression in the student population.

As a possible bias in the results, the study has no data on the 190 non-participating students. Since we lack data on these individuals, their exclusion may have biased the results.

\section{CONCLUSIONS}

This study showed a higher prevalence of depressive symptoms in medical students than in the general population, with the rate of symptoms influenced by the following variables: course satisfaction, whether the student was local or from out-of-town, and consistency with original expectations. Incidence of depressive symptoms was not uniform during the course, but was continuous.

The main conclusion is that medical school involves increased vulnerability to the onset of depressive symptoms.

Dissatisfaction with the course and frustration of expectations were factors associated with this vulnerability. Students from out of town (from the interior of the State, for example) were also more vulnerable to depressive symptoms.

Based on the results, a student support center like PROAC provided by the institution may not be sufficient to help students. This may be due to students' difficulty in seeking and accepting help for treatment of depression.

\section{REFERENCES}

1. Adewuia AO, Ola BA, Aloba OO, Mapayi BM, Oginni OO. Depression amongst Nigerian university students: prevalence and sociodemographic correlates. Soc Psychiatry Psychiatr Epidemiol. 2006;20:1-5.

2. Eric L, Radovanovic Z, Jevremovic I. Mental disorders among Yugoslav medical students. Brit J Psychiatry. 1988;152:127-9.

3. Giglio JS. Bem-estar emocional em estudantes universitários. Campinas; 1975. [PhD Dissertation in Medical Sciences]- Universidade Estadual de Campinas.

4. Segal BE. Epidemiology of emotional disturbance among college undergraduates: a review and analysis. J Nerv Ment Dis. 1966;143:348-62. 
5. Hahn MS, Ferraz MPT. Características da clientela de um programa de saúde mental para estudantes universitários brasileiros. Rev ABP-APAL. 1998;20(2):45-53.

6. Millan LR, Rossi E, De Marco OLN. A procura espontânea de assistência psicológica pelo estudante de medicina. Rev ABP-APAL. 1995;17(1):11-6.

7. Niemi T. Use of the mental health care services in Finland by students in different fields of study. J Amer Coll Health. 1984;33:123-5.

8. Nucette LM. Evaluación médico psicológica en estudiantes de medicina. Arch Venez Psiquiatr y Neurol. 1985;31(65):51-60.

9. Chan WD. Coping with depressed mood among Chinese medical students in Hong Kong. J Affect Disord. 1992;24:109-16.

10. Clark DC, Zeldow PB. Vicissitudes of depressed mood during four years of medical school. JAMA. 1988;260:2521-8.

11. Cordás TA, Sendacs AM, Gonzales D. Ideação e tentativa de suicídio em uma população de estudantes de medicina. Rev ABP-APAL. 1988;10:100-2.

12. Galli SE, Feijó LL, Roig RI, Romero ES. Aplicación del "MINI" como orientación diagnóstica en estudiantes de medicina de la Universidad Peruana Cayetano Heredia: informe preliminar epidemiológico. Rev Med Hered. 2001;13(1):19-25.

13. Lloyd C, Gartrell NK. Psychiatric symptoms in medical students. Compr Psychiatry. 1984;25:552-65.

14. Lloyd C. Sex differences in medical students requesting psychiatric intervention. J Nerv Ment Dis. 1983;171(9):535-45.

15. Zoccolillo M, Murphy GE, Wetzel RD. Depression among medical students. J Affect Disord. 1986;11:91-6.

16. Ross M. Suicide among physicians: a psychological study. Dis Nerv Syst. 1973;31:145-50.

17. Lim M. Physician Depression and Suicide. Virtual Mentor. 2003; 5(9).

18. Millan LR, Barbedo MF. Assistência psicológica ao aluno de medicina: o início de uma experiência. Rev Bras Educ Méd. 1988;12(1):1-40.

19. Stewart SM, Betson C, Marshall I, Wong CM, Lee PW, Lam TH. Stress and vulnerability in medical students. Med Educ. 1995;29(2):119-27.

20. Beck AT, Ward CH, Mendelson M, Mock J, Erbaugh J. An inventory for measuring depression. Arch Gen Psychiatry. 1961;4:561-71.
21. Gotlib IH. Depression and general psychopathology in university students. J Abnorm Psychol. 1984;93:19-30.

22. Oliver JM, Simmons ME. Depression as Measured by the DSM-III and Beck Depression Inventory in an Unselected Adult Population. J Consult Clin Psychol. 1984;52:892-898.

23. Tanaka-Matsumi J, Kameoka VA. Reliabilities and Concurrent Validities of Popular Self-Report Measures of Depression, Anxiety, and Social Desirability. J Consult Clin Psychol. 1986;54:328-333.

24. Louks J, Hayne C, Smith J. Replicated Factor Structure of the Beck Depression Inventory. J Nerv Ment Dis. 1989;177:473-479.

25. Beck AT, Steer RA, Garbin MG. Psychometric properties of the Beck Depression Inventory: Twenty-five years of evaluation. Clin Psychol Rev. 1988;8(1):77-100.

26. Porcu M, Fritzen CV, Helber C. Sintomas depressivos nos estudantes de medicina da Universidade Estadual de Maringá. Psiquiatr Prat Méd. (São Paulo). 2001;34:2-6.

27. Bourque P, Beaudette D. Étude Psychometrique du Questionnaire de Dépression de Beck Auprès D'un Échantillon D'étudiants Universitaires Francophones. Can J Behav Sci. $1982 ; 14: 211-218$.

28. Conde C, Useros E. Adaptación castellana de la escala de evaluación conductual para la depresión de Beck. Rev Psiquiat Psicol Med Eur Am Lat. 1975;12:217-36.

29. Gorestein C, Andrade L. Inventário de depressão de Beck: propriedades psicométricas da versão em português. Rev Psiquiatr Clín. (São Paulo). 1998;25:245-50.

30. Almeida-Filho N, Mari JJ, Coutinho E, França JF, Fernandes J, Andreoli SBA, et al. Brazilian multicentric study of psychiatric morbidity - Methodological features and prevalence estimates. Br J Psychiatr. 1997;171:524-9.

31. Moro A, Valle JB, Lima LP. Sintomas depressivos nos estudantes de medicina da Universidade da Região de Joinville (SC). Rev Bras Educ Med. 2005;29(2):97-102.

32. Hickie IB, Davenport TA, Luscombe GM, Rong Y, Hickie ML, Bell MI. The assessment of depression awareness and help-seeking behaviour: experiences with the International Depression Literacy Survey. BMC Psychiatry. 2007;7:48. Doi:10.1186/1471-244X-7-48

33. Dahlin ME, Runeson B. Burnout and psychiatric morbidity among medical students entering clinical training: a three-year prospective questionnaire and interview-based study. BMC Med Educ. 2007;7:6. Doi:10.1186/1472-6920-7-6

34. Rosenthal JM, Okie S. White Coat, Mood Indigo - Depression in Medical School. N Engl J Med. 2005;353(11):1085-8. 
35. Meleiro AMAS. Suicídio entre médicos e estudantes de medicina. Rev. Assoc. Med. Bras. 1998;44(2):135-40.

36. Cavestro JM, Rocha FL. Prevalência de depressão entre estudantes universitário. J Bras Psiquiatr. 2006;55(4):264-7.

37. Center C, Davis M, Detre T. Confronting depression and suicide in physicians: a consensus statement. JAMA. 2003;286:3161-3166.

38. Díaz LJ, Lio-Coo VT, Zerquera EU, Puebla RM, Darías IF, Monteagudo MC. Factores psicosociales de la depresion. Rev Cuba Med Mil. 2006; 35(3).

39. Díaz LA, Campos A, Rueda GE, Barros JA. Propuesta de una version abreviada de la escala de Zung para depression. Colomb Med. 2005; 36:168-172.

40. Zonta R, Robles ACC, Grosseman S. Estratégias de enfrentamento do estresse desenvolvidas por estudantes de medicina da Universidade Federal de Santa Catarina). Rev Bras Educ Med. 2006;30(3):147-153.

\section{AUTHORS' CONTRIBUTIONS}

All of the authors collaborated in the data collection and analysis and writing of the article.

\section{DISCLOSURE}

The authors had no conflicts of interest.

\section{ENDEREÇO PARA CORRESPONDÊNCIA}

Paula Natalie Arraes Guedes Macedo

Rua Jorge Tibiriçá, 6/81

Santos

CEP.: 11055-250 SP

E-mail: paulanatalie@gmail.com 